Rev. Mus. Argentino Cienc. Nat., n.s.

2(1): $23 \cdots 26,2000$

Buenos Aires. ISSN 1.514-5158

\title{
Wood anatomy of six species of Lycium, with comments on fibriform vessel elements
}

\author{
Carlos Alejandro NORVERTO \\ Proyecto Forestal de Desarrollo (SAGPyA/BIRF). Av. Paseo Colón 922, 1063 Buenos Aires, Argentina
}

\begin{abstract}
The study of wood anatomy of 6 species of Lycium $\mathrm{L}$. was made. These species share an homogeneous structure. The essential wood characteristics are: dendritic distribution, presence of spiral thickness in the secondary wall of vascular elements and tracheids, apotracheal and paratracheal axial parenchyma, radial heterogeneous, and libriform fibres. The presence of fibriform vessel element is described in six species of Lycium for the first time.
\end{abstract}

Kaey words: vessel tracheids, wood anatomy, Lycium, Solanaceae.

This paper is a further contribution to a series describing the wood anatomy of Lycium indigenous to Argentina (Norverto, 1988; 1989). Lycium comprises $75-80$ species of shrubs and small trees widely distributed in all the world (Hunziker, 1979; Bernardello, 1986). From the 22 species of Argentina only L. ciliatum Schlecht., $L$. elongatum Miers, $L$. chilense Miers, $L$. gilliesianum Miers, $L$. infaustum Miers and $L$. tenuispinosum Miers were studied, belonging to arid and semiarid regions (Cabrera, 1971).

\section{MATERIALS AND METHODS}

Wood samples have been obtained from the following Argentine Herbaria:

BAw: Museo Argentino de Ciencias Naturales "B. Rivadavia".

MERL: Herbario "Ruíz Leal", Mendoza.

SL: Universidad Nacional de San Luis.

SRFA: Universidad Nacional de La Pampa, Facultad de Agronomía de Santa Rosa.

Lycium cestroides. Cozzo (BAw 52297), Cór doba Prov.; Patridge (BAw 68440), Corrientes Prov. -Lycium ciliatum. Cozzo (BAw 52295), Córdoba Prov,; Troiani \& Prina (SRFA 9734), La Pampa Prov. -Lycium chilense var, chilense. Troiani \& Prina (SRFA 9732). La Pampa Prov. Lycium chilense var. minutifolium Troiani \& Prina (SRFA 9733), La Pampa Prov. -Lycium chilense var. glaberrinum. Del Vitto (SL 2269), San Luis Prov.; Roig (MERL 12499), Mendoza Prov. -Lycium elongatum. Castellanos (BAw 11697), Córdoba Prov,; Luna Ruíz (BAw 53405),
Santiago del Estero Prov. -Lycium gilliesianum. Norverto (BAw 74970); 75015), La Pampa Prov. -Lycium infaustum. Lorentz (BAw 41223), Santiago del Estero Prov. -Lycium tenuispinosum. Troiani, Prina \& Alfonso (SRFA 9617), La Pampa Prov.

The samples in dried conditions were boiled in water and stored in 50\% aqueous ethyl alcohol. With a sliding microtome, transversal, longitudinal tangential and radial sections of approximately $13 \mu \mathrm{m}$ thick were prepared. Thicker sections were out only in order to reduce tearing. Maceration's were prepared with Boodle' $s$ method (1916). Sections and maceration's were stained with safranin-fast green combination and made into permanent slides. All quantitative data are based upon 25 measurements per feature. Terminology follows that of the IAWA Committee on Nomenclature (1964) and IAWA list of microscopic features for hardwood identification (Wheeler et. al,, 1989). Of the mentioned codes for the materials, only BAw is included in the Stern's Index Xilariorum (1991).

\section{RESULTS}

Wood semi-ring porous. Vessels in dendritic pattern, solitary, in clusters or radial and tangential short multiples; oval or angular in transverse section; average tangential diameter $47 \mathrm{\mu m}$. Simple perforation plates in obliques to lightly obliques end walls. Tails present on vessel elements (Fig. 1). Intervessel pits alternate; inner apertures included. Vessel-ray and vessel- 


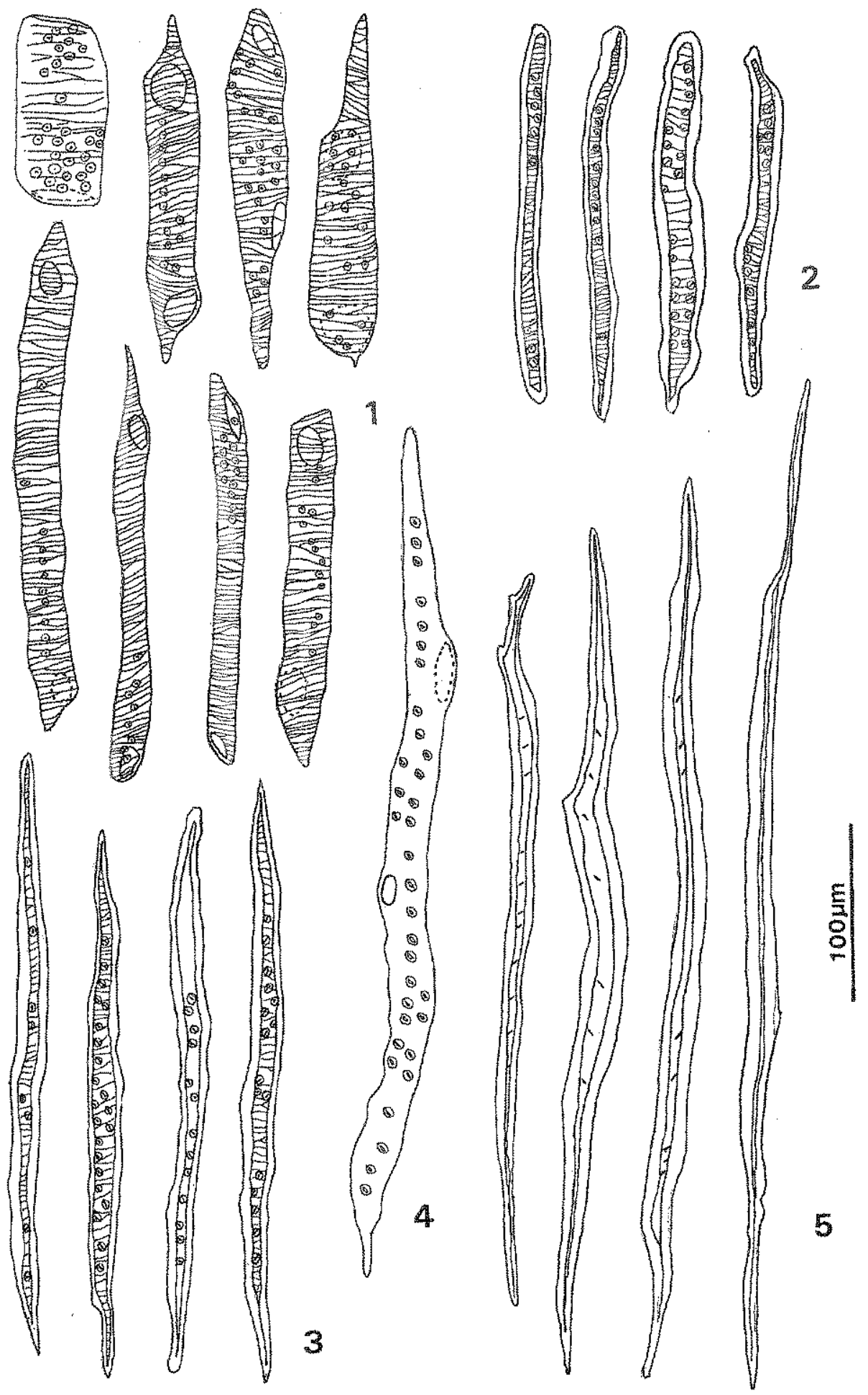

Figs. 1-5. Graphics of cells from macerated wood of Lycium chilense. 1, Vessels elements. 2, Tracheids. 3, Fibre - tracheids. 4, Fibriform vessel element. 5, Libriform fibres. 

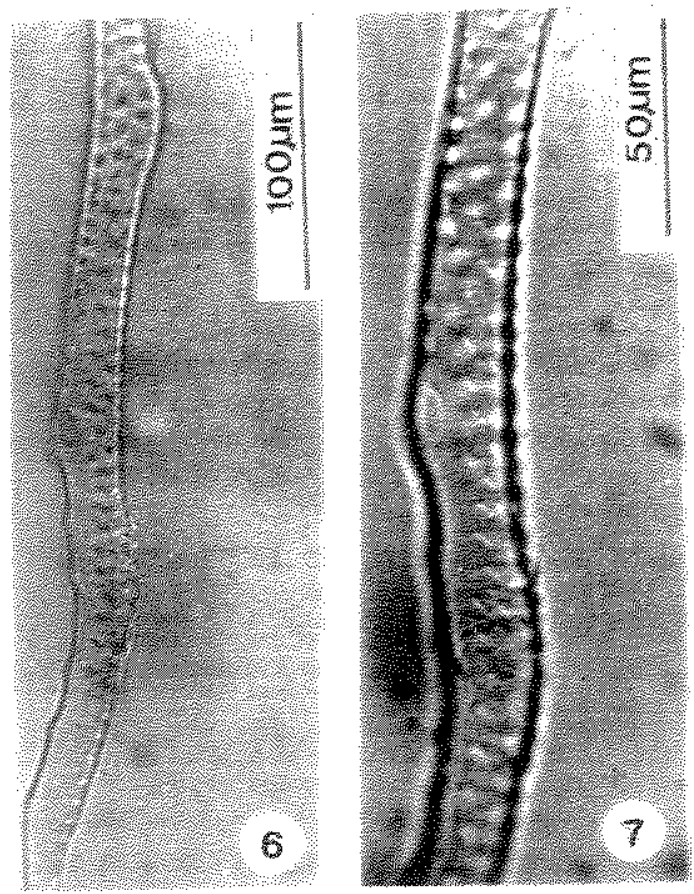

Figs. 6-7. Photomicrographs of Lycium cestroides: fibriform vessel elements, lateral perforation plates.

parenchyma pits with distinct borders, similar in size and shape. Walls with helical thickenings (Fig. 1). Tyloses and gummy deposits absent. Tracheids with helical thickenings in the walls and bordered pits (Fig. 2). Fibre-tracheids with distinctly bordered pits in tangential and radial walls, inner apertures included; on average 344 $\mu \mathrm{m}$ long; spiral thickenings present (Fig. 3). Libriform fibres with simple pits; on average 583 $\mu \mathrm{m}$ long (Fig 5). Fibriform vessel elements present (Fig. 4), perforation plates are lateral and tend to be vertically oriented (Figs. 6, 7), they may very much like fibres; tend to be longer than the ordinary vessel elements that they accompany, on average $430 \mu \mathrm{m}$ long. Axial parenchyma scanty paratracheal and diffuse apotracheal. L. gilliesianum also with axial parenchyma in marginal bands. Rays uniseriate or partially biseriate; homocellular and heterocellular; ray cells square, upright and procumbent. Disjunctive parenchyma present. Calcium oxalate crystals in axial parenchyma and sometimes in radial parenchyma.

\section{DISCUSSION}

Certain groups of dicotyledons have fibriform vessel elements (Woodworth, 1935; Carlquist, 1988). In the present study fibriform vessel elements were found for the first time in the Solanaceae. Lycium has fibriform vessel elements of fusiform shape, the tips of witch extend well beyond perforation plates. It also has been reported the presence of fibriform vessel elements in other families of Tubiflorales (Melchior, 1964); Convolvulaceae (Mennega, 1969); Hydrophyllaceae (Carlquist et al., 1983; Carlquist and Eckhart, 1984); and Polemoniaceae (Carlquist et al., 1984).

Since the present, Tubiflorales is the group with major number of species characterised by the presence of fibriform vessel elements.

Vessels in dendritic pattern and helical thickenings in the walls of vessel elements, tracheids and fibre-tracheids are indicative features of wood xeromorphy (Norverto, 1989; Carlquist, 1992).

\section{ACKNOWLEDGEMENTS}

I thank Dr. Sherwin Carlquist for his critical reading of the manuscript. I thank also the curators for the herbarium samples received.

\section{BIBLIOGRAPHY}

Bernardello, L.M. 1986. Revisión taxonómica de las especies sudamericanas de Lycium (Solanaceae. Bol. Acad. Nac. Ci. Córdoba 57 (3-4): 173-356.

Boodle, L. A. 1916. A method of macerating fibres. Kew Bull. Misc. Inf. 4: 108-110.

Cabrera, A.L. 1971. Fitogeografía de la República Argentina. Bol. Soc. Argent. Bot. $14(1-2)$ : 1-42.

Carlquist, S. 1988. Comparative wood anatomy. Springer - Verlag. Berlin \& Heidelberg.

- 1992. Wood anatomy of Solanaceae: a survey. Allertonia, $6(4)$ : 279-326.

Carlquist, S., V. M. Eckhart \& D. C. Michener. 1983. Wood anatomy of Hydrophyllaceae. I Eriodictyon. Aliso 11:317-335.

- 1984. Wood anatomy of Polemoniaceae. Aliso 102: $547-572$.

Carlquist, S. \& V. M. Eckhart. 1984. Wood anatomy of Hydrophyllaceae II. Genera other than Eriodictyon, with comments on parenchyma bands containing vessels with large pits. Aliso 10: 397412.

Hunziker, A.T. 1979. South American Solanaceae: a synoptic survey. In J. C. Hawkes, R. N. Lester a A. D. Skelding (eds.). the Biology and Taxonomy of the Solanaceae. Linnean Soc.. Symp. Ser. 7: 49 85 . 
IAWA Committee on Nomenclature. 1964. Multilingual glossary of terms used in wood. anatomy. Konkordia. Winterthur.

Melchior, H. 1964. Engler's Syllabus der Pflanzenfamilien. 12. Ed. Berlin, Nikolasse.

Mennega A. M. W. 1969. The wood structure of Dicranostyles (Convolvulaceae). Acta Bot. Neerl. 18: $173-179$.

Norverto, C. A. 1988. Nota preliminar sobre la estructura de la madera de Lycium gilliesianum Miers (Solanaceae). Rev. Cs. Agrarias y Tecnología de los Alimentos (UCA) 9 (1-4): 63-67.

- 1989. Estudio comparativo de la estructura de la madera de Lycium cestroides y L. elongatum
(Solanaceae). Bol. Soc. Argent. Bot. 26 (1-2): 4552.

Stern, W. L. 1991. Index Xylariorum, institutional wood collections of world. Addendum. IAWA Bull. 12 (1): 99.

Wheeler, E. A., P. Baas and P. E. Gasson. 1989. IAWA list of microscopic features for hardwood identification (new series) 10 (3): 219-332. Leiden The Netherlands.

Woodworth, R.H. 1935. Fibriform vessel members in Passiflora. Tropical Woods 41: 8-16.

Recibido: 15-XI-1998 Aceptado: 27-XII-1999 